\title{
Predicting Dissolved Phosphorus in Runoff from Manured Field Plots
}

\author{
P. A. Vadas,* B. E. Haggard, and W. J. Gburek
}

\begin{abstract}
Dissolved inorganic $P$ transport in runoff from agricultural soils is an environmental concern. Models are used to predict $\mathbf{P}$ transport but rarely simulate $P$ in runoff from surface-applied manures. Using field-plot data, we tested a previously proposed model to predict manure $P$ in runoff. We updated the model to include more data relating water to manure ratio to manure $P$ released during water extractions. We verified that this update can predict $P$ release from manure to rain using published data. We tested the updated model using field-plot and soil-box data from three manure runoff studies. The model accurately predicted runoff $P$ for boxes, but underpredicted runoff $P$ for plots. Underpredictions were caused by runoff to rain ratios used to distribute $P$ into runoff or infiltration. We developed $P$ distribution fractions from manure water extraction data to replace runoff to rain ratios. Calculating $P$ distribution fractions requires knowing rainfall rate and times that runoff begins and rain stops. Using $\mathbf{P}$ distribution fractions gave accurate predictions of runoff $\mathbf{P}$ for soil boxes and field plots. We observed relationships between measured runoff to rain ratios and both $P$ distribution fractions and a degree of error in original predictions, calculated as (measured runoff $P$ /predicted runoff $P$ ). Using independent field-plot data, we verified that original underpredictions of manure runoff $P$ can be improved by calculating $P$ distribution fractions from measured runoff to rain ratios or adjusting runoff to rain ratios based on their degree of error. Future work should test the model at field or watershed scales and at longer time scales.
\end{abstract}

$\mathrm{N}$ ONPOINT-SOURCE POLLUTION of fresh waters by P continues to be a water quality concern because it contributes to accelerated eutrophication and subsequent limitation of water use for drinking, recreation, and industry (Carpenter et al., 1998; Gibson et al., 2000; Sharpley and Rekolainen, 1997). Transport of P through leaching can occur in sandy, organic, and artificially drained soils (Heckrath et al., 1995; Novak et al., 2000; Porter and Sanchez, 1992), but the major P transport pathway for most agricultural soils is surface runoff. Although soil and plant material can be significant sources of P to runoff, their effect is overwhelmed by $P$ release from recently applied and unincorporated manures and fertilizers (Eghball and Gilley, 1999; Kleinman and Sharpley, 2003; Moore et al., 2000). Surface application of manure is a common practice in the United States, and recent studies show the quantity of water-extractable phosphorus (WEP) applied to soils

P.A. Vadas and W.J. Gburek, USDA-ARS, Pasture Systems and Watershed Management Research Unit, Building 3702, Curtin Road, University Park, PA 16802-3702. B.E. Haggard, USDA-ARS, Poultry Production and Product Safety Research Unit, 203 Engineering Hall, Fayetteville, AR 72701. Received 10 Nov. 2004. *Corresponding author (Peter.Vadas@ars.usda.gov).

Published in J. Environ. Qual. 34:1347-1353 (2005).

Technical Reports: Surface Water Quality

doi:10.2134/jeq2004.0424

(c) ASA, CSSA, SSSA

677 S. Segoe Rd., Madison, WI 53711 USA in manures is a major factor controlling dissolved $\mathrm{P}$ concentrations in runoff shortly after manure application (DeLaune et al., 2004; Kleinman et al., 2002).

Computer simulation models are designed to quantify field-scale or watershed-scale P transport, but commonly used models, such as EPIC (Williams et al., 1983), GLEAMS (Leonard et al., 1987), ANSWERS (Bouraoui and Dillaha, 1996), or SWAT (Arnold et al., 1998), do not simulate surface application of manures or direct transfer of $\mathrm{P}$ from manures to runoff. The result is a poor representation and often underprediction of $\mathrm{P}$ in runoff (Pierson et al., 2001; Sharpley et al., 2002). If such models are to be used in settings where surface application of manure is common, they should be modified to simulate $\mathrm{P}$ in runoff from manures.

Vadas et al. (2004) developed a simple model to predict dissolved inorganic $\mathrm{P}$ release from manures to rain water using laboratory water extraction data of Kleinman et al. (2002) and simulated rainfall data of Sharpley and Moyer (2000). Vadas et al. (2004) extended the model to successfully predict dissolved inorganic $\mathrm{P}$ concentrations in runoff from small boxes packed with soil and treated with manures. Because manure water extraction data from Kleinman et al. (2002) was limited, our first objective was to supplement their data with that from more manure extractions. Because hydrology of soil boxes differs greatly from natural field hydrology or even field-plot hydrology (Kleinman et al., 2004), our second objective was to test the manure $\mathrm{P}$ runoff model of Vadas et al. (2004) at the field-plot scale.

\section{MATERIALS AND METHODS}

\section{Manure Water Extractions}

We collected five manures for WEP analysis. They included two dairy manures from lactating Friesian cows with and without bedding material, a swine slurry from finishing sows that had been washed into holding tanks and agitated before sampling, and two poultry litters from Texas and Pennsylvania that were a mixture of manure and sawdust-wood chip bedding material. We analyzed manures for dry matter gravimetrically after drying at $105^{\circ} \mathrm{C}$ for $48 \mathrm{~h}$. We analyzed fresh manures for WEP by shaking them with deionized water for $1 \mathrm{~h}$ at water to manure ratios of 10:1, 50:1, 100:1, 150:1, 200:1, and 250:1. All ratios were on a dry weight equivalent basis and accounted for any water in fresh manures. We filtered all solutions through $0.45-\mu \mathrm{m}$ filters, and analyzed them for P by the method of Murphy and Riley (1962).

We also used data from Haggard (unpublished data, 2005) where six different poultry manures were analyzed for WEP using water to mass ratios of fresh poultry litter of 10:1, 20:1, 50:1, 100:1, and 200:1. Samples were shaken in a reciprocating shaker for $2 \mathrm{~h}$, centrifuged, filtered through $0.45-\mu \mathrm{m}$ filters, and acidified to $\mathrm{pH}<2$ using concentrated $\mathrm{HCl}$. Filtered,

Abbreviations: $W$, water to manure ratio; WEP, water-extractable phosphorus. 
acidified aliquots were analyzed for $\mathrm{P}$ using the automated ascorbic acid reduction method (American Public Health Association, 1992).

\section{Field-Plot and Soil-Box Runoff Experiments}

We used data from field-plot studies of Haggard et al. (2003) and Smith et al. (2004) where various poultry litters had been surface-applied and subjected to simulated rain. Runoff experiments were conducted at the University of Arkansas Agricultural Experiment Station, Fayetteville, Arkansas, where small, grassed plots $(1.52 \times 6.10 \mathrm{~m})$ on a Captina silt loam soil (finesilty, siliceous, active, mesic Typic Fragiudult) were selected. Plots had a 5\% slope and were hydrologically isolated using $15-\mathrm{cm}$ metal borders inserted vertically into the soil so that $5 \mathrm{~cm}$ of the borders were above the soil surface. An Al trough at the down-slope end collected surface runoff. Poultry litters were applied at a various rates, and initial rain simulations were conducted within $72 \mathrm{~h}$ of application. Plots received rain at $50 \mathrm{~mm} \mathrm{~h}^{-1}$ until $30 \mathrm{~min}$ of continuous runoff was observed. The time from the onset of rain to the onset of runoff was recorded. Flow-weighted composite runoff samples were collected to represent the entire 30 min of runoff, filtered through $0.45-\mu \mathrm{m}$ filters, and analyzed for $\mathrm{P}$ using the automated ascorbic acid reduction method (American Public Health Association, 1992). Haggard et al. (2003) conducted two consecutive rains, and Smith et al. (2004) conducted three consecutive rains on the same plots. Rains had $7-d$ intervals, and any natural rain in-between was noted.

We also used soil-box runoff data from Kleinman et al. (2004). Soils were packed into small $(100 \mathrm{~cm}$ long by $20 \mathrm{~cm}$ wide by $7.5 \mathrm{~cm}$ deep) stainless steel boxes and leveled to a depth of $5 \mathrm{~cm}$. Soils were pre-wet $72 \mathrm{~h}$ before runoff experiments, and boxes were placed at a 5\% slope under a rain simulator based on the design of Miller (1987). Fresh dairy, poultry, or swine manure was surface-applied to boxes at a rate of $100 \mathrm{~kg}$ total manure $\mathrm{P} \mathrm{ha}^{-1}$. Seventy-two hours later, rain was applied at an approximate intensity of $75 \mathrm{~mm} \mathrm{~h}^{-1}$ until 30 min of runoff was observed. The time from the onset of rain to the onset of runoff was recorded, and runoff samples were filtered through $0.45-\mu \mathrm{m}$ filters and analyzed for $\mathrm{P}$ by the method of Murphy and Riley (1962). Kleinman et al. (2004) conducted two runoff experiments at 72 and $96 \mathrm{~h}$ after manure application.

\section{Phosphorus Runoff Model Testing}

Vadas et al. (2004) developed simple equations to predict dissolved $\mathrm{P}$ release $\left(\mathrm{mg} \mathrm{kg}^{-1}\right)$ from manure to rain water based on laboratory manure extraction data of Kleinman et al. (2002). The Kleinman et al. (2002) data showed that as the water to manure ratio $\left(\mathrm{cm}^{3} \mathrm{~g}^{-1}\right)$ of extractions increases, the amount of manure $\mathrm{P}$ extracted $\left(\mathrm{mg} \mathrm{kg}^{-1}\right)$ also increases. Figure 1 shows manure WEP data from Kleinman et al. (2002) combined with data from our current study and Haggard (unpublished data, 2005). Manure WEP data are expressed as a relative fraction of WEP measured at water to manure ratios of approximately 250:1, which Vadas et al. (2004) proposed to be a good estimate of maximum WEP in fresh manures. We observed consistent relationships between water to manure ratios and manure WEP across data sets. Therefore, we updated the equations of Vadas et al. (2004) used to predict manure $P$ release to rain water. Because data showed evidence of nonlinearity between water to manure ratio and WEP, we fitted a second-order reaction equation to all data with the Marquardt least-squares method in SAS Version 8 (SAS Institute, 1999). There was little difference in results for poultry

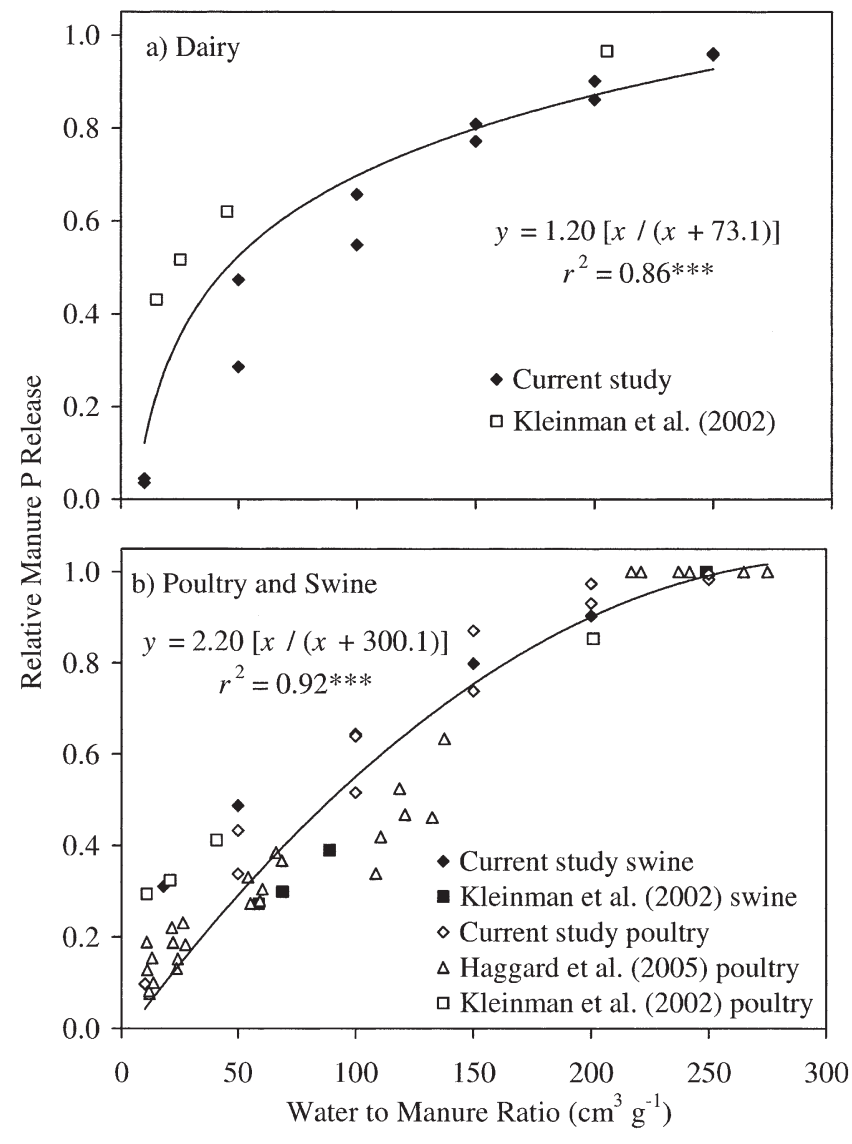

Fig. 1. Relationship between water to manure ratio $\left(W ; \mathrm{cm}^{3} \mathrm{~g}^{-1}\right)$ and manure water-extractable phosphorus (WEP), as expressed relative to WEP extracted at a $W$ of 250:1. Data are from Haggard (unpublished data, 2005), Kleinman et al. (2002), and our current study. The symbol $* * *$ designates significance at the 0.001 probability level.

and swine manures, so we combined them into one data set. Overall, $\mathrm{P}$ release from the manure types $\left(\mathrm{mg} \mathrm{kg}^{-1}\right)$ was thus described for dairy as:

$$
\begin{aligned}
\text { manure P release }= & {[1.2 W /(W+73.1)] } \\
& (\text { manure WEP })
\end{aligned}
$$

and for poultry and swine as:

$$
\begin{aligned}
\text { manure P release }= & {[2.2 W /(W+300.1)] } \\
& (\text { manure WEP })
\end{aligned}
$$

where $W$ is the water to manure ratio $\left(\mathrm{cm}^{3} \mathrm{~g}^{-1}\right)$, and manure WEP $\left(\mathrm{mg} \mathrm{kg}^{-1}\right)$ is that $\mathrm{P}$ extracted from fresh manures at a water to manure ratio of 250:1 for $1 \mathrm{~h}$, with extracts filtered through $0.45-\mu \mathrm{m}$ filters and analyzed colorimetrically. The expression multiplied by manure WEP in Eq. [1] and [2] is designed to be a unitless fraction ranging from 0.0 to 1.0 , and not exceeding 1.0. Following the same procedure as Vadas et al. (2004), we verified the ability of Eq. [1] and [2] to predict $P$ release from manures to simulated rainfall using the independent data set of Sharpley and Moyer (2000) (Fig. 2). Therefore, the equations can accurately predict $\mathrm{P}$ release from manure to rain water for a variety of manure types across several rainfalls. According to the model of Vadas et al. (2004), Eq. [1] and [2] can then be extended to predict dissolved $\mathrm{P}$ concentrations in runoff $\left(\mathrm{mg} \mathrm{L}^{-1}\right)$ for dairy manure as: 


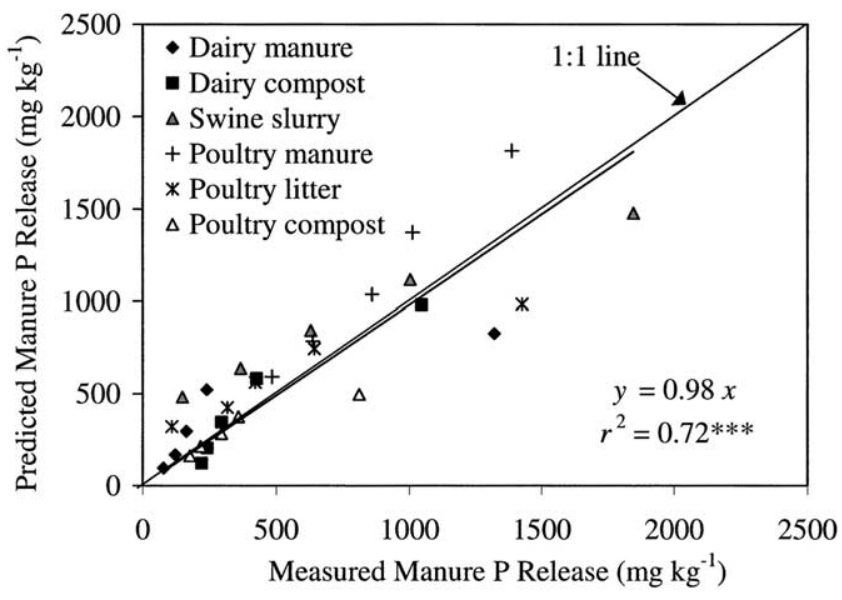

Fig. 2. Relationship between dissolved inorganic $P$ release from manure to simulated rain water as measured by Sharpley and Moyer (2000) and as predicted using Eq. [1] and [2]. The symbol *** designates significance at the 0.001 probability level.

$$
\begin{aligned}
\text { runoff } \mathrm{P}= & {[1.2 W /(W+73.1)](\text { manure WEP }) } \\
& (0.4)(\text { runoff } / \text { rain }) /(W)
\end{aligned}
$$

and for poultry and swine manure as:

$$
\begin{aligned}
\text { runoff } \mathrm{P}= & {[2.2 W /(W+300.1)](\text { manure WEP }) } \\
& (0.4)(\text { runoff } / \text { rain }) /(W)
\end{aligned}
$$

where the runoff to rain ratio is a unitless parameter, such as $\mathrm{cm} \mathrm{cm}^{-1}$, designed to distribute $\mathrm{P}$ released from manure into either runoff or infiltrating water. The 0.4 adjustment factor for dairy and swine manures is for only slurries, where slurry liquid and a subsequent portion of manure WEP infiltrates into soil immediately after application. This 0.4 factor is used for only the first rain after manure application. The value of 0.4 is slightly different from those proposed by Vadas et al. (2004), but better matches a value observed during slurry infiltration experiments with soil columns (P.A. Vadas, unpublished data, 2005).

We tested Eq. [3] and [4] for their ability to predict dissolved $P$ concentrations in runoff for soil-box experiments of Kleinman et al. (2004) and field-plot studies of Haggard et al. (2003) and Smith et al. (2004). For consecutive rain simulations in these studies, we subtracted the amount of predicted $\mathrm{P}$ released from manures during the first rain from the initial amount of manure WEP on the right hand side of Eq. [3] and [4]. We used resulting differences as new values for WEP to predict $\mathrm{P}$ release for the second rain. We carried this method through to predict $\mathrm{P}$ release for the third rain of Smith et al. (2004). There were two small natural rains $(5$ and $10 \mathrm{~mm})$ inbetween rain simulations for Smith et al. (2004), and one rain larger $(150 \mathrm{~mm})$ for Haggard et al. (2003). We also predicted leaching of $\mathrm{P}$ from manures by these natural rains to have accurate estimates of manure WEP at the start of subsequent rain simulations. For all studies, we assumed the mass of manure on the soil surface, as used to calculate $W$ values in Eq. [2], was constant for all rain events.

\section{RESULTS AND DISCUSSION \\ Predicting Dissolved Reactive Phosphorus in Runoff}

For field-plot data of Haggard et al. (2003) and Smith et al. (2004) there was a significant relationship between
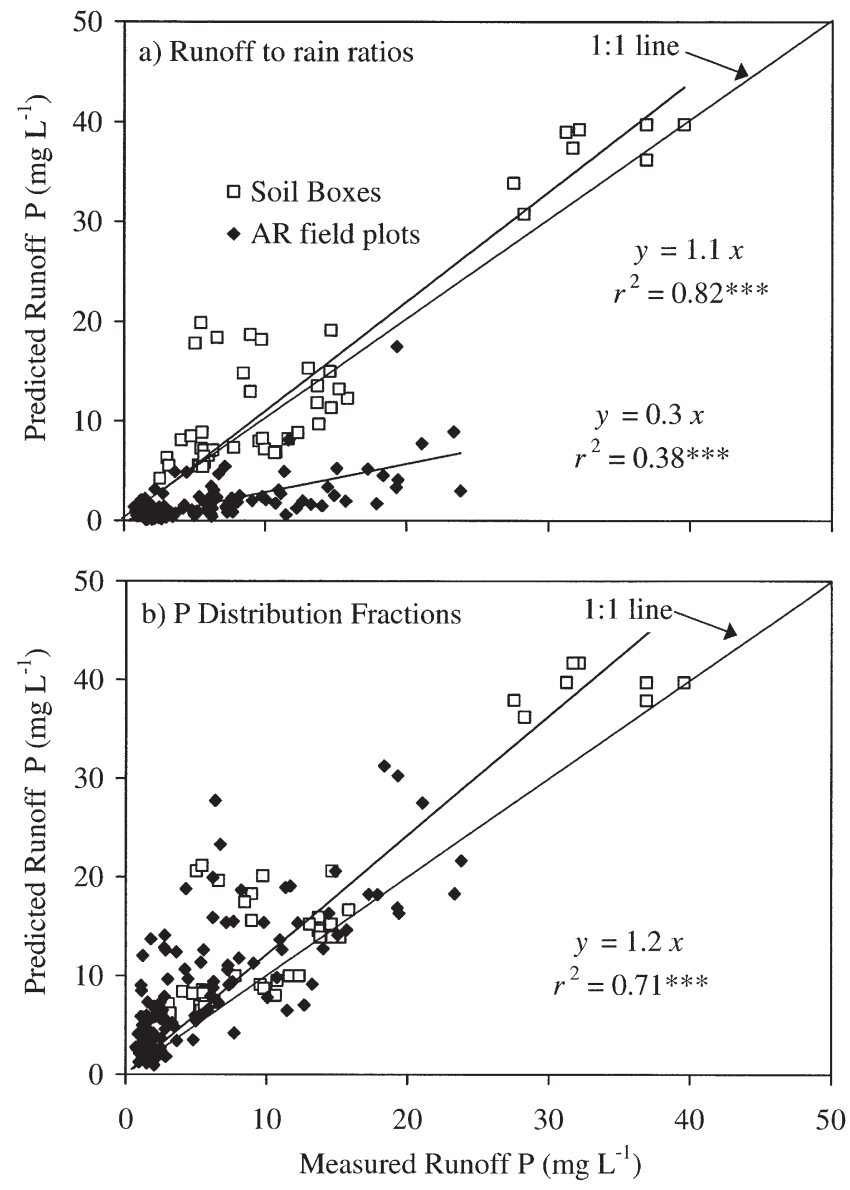

Fig. 3. Relationship between dissolved inorganic $\mathbf{P}$ concentrations in runoff from soil boxes and field plots where manures had been surface-applied and subjected to simulated rain. Data are as measured by Haggard et al. (2003), Kleinman et al. (2004), and Smith et al. (2004), and as predicted by Eq. [3] and [4], using either (a) measured runoff to rain ratios or $(b)$ calculated $P$ distribution fractions to distribute $P$ released from manure into runoff or infiltrating water. The symbol $* * *$ designates significance at the 0.001 probability level.

measured and predicted inorganic $\mathrm{P}$ concentrations in runoff, but with Eq. [3] and [4] considerably underpredicting runoff $\mathrm{P}$ (Fig. 3a). For soil-box data of Kleinman et al. (2004), Eq. [3] and [4] accurately predicted $\mathrm{P}$ in runoff. Vadas et al. (2004) also showed that equations very similar to Eq. [3] and [4] can successfully predict $\mathrm{P}$ in runoff from soil boxes treated with surface-applied manures when runoff to rain ratios are used in the prediction equations. Based on the manure $\mathrm{P}$ leaching prediction results using Eq. [1] and [2] (Fig. 2), we assume that Eq. [3] and [4] will successfully predict $\mathrm{P}$ leaching from manures by rain whether manures are applied to soil boxes or field plots. The inability of Eq. [3] and [4] to accurately predict $\mathrm{P}$ in runoff from field plots may instead be related to runoff hydrology differences between soil boxes and field plots and ultimately to runoff to rain ratios in the equations. The assumptions behind the runoff to rain ratio are that the rate of $\mathrm{P}$ release from manure to rain water during a storm decreases with time, that a greater runoff to rain ratio implies that runoff starts earlier during the storm, and that more $\mathrm{P}$ 
released from manure is thus transferred to runoff as the runoff to rain ratio increases. Vadas et al. (2004) showed that the runoff to rain ratio was needed in their model to distribute manure $\mathrm{P}$ into either runoff or infiltrating water and accurately predict $\mathrm{P}$ in runoff from soil boxes. Apparently, a simple measured runoff to rain ratio cannot do the same for field-plot data. Therefore, we sought a method to adjust the runoff to rain ratio so its underlying assumptions were preserved but predictions of dissolved inorganic $\mathrm{P}$ concentrations in runoff from field plots were more accurate.

\section{Adjusting the Runoff to Rain Ratio}

We started with data from manure water extractions and the relationships between manure WEP and $W$ (Fig. 1). These data essentially show the dynamics of $\mathrm{P}$ release from manure to rain water as a storm progresses and $W$ increases. In Fig. 4, we plotted these manure WEP data and gave an example, using runoff data from one field plot of Smith et al. (2004), of how we calculated new $\mathrm{P}$ distribution fractions to replace runoff to rainfall ratios in Eq. [3] and [4]. We use the term "P distribution fraction" because it is designed to distribute manure WEP released by rain into either infiltrating or runoff water. For the data of Smith et al. (2004), we first determined the value of $W(47.0)$ when runoff began from recorded data of time to runoff and rainfall rate. We similarly determined a $W$ value (84.0) at the time that rain stopped. Using the relationship between $W$ and relative manure WEP shown in Fig. 4, we then determined corresponding fractions of manure WEP released ( 0.33 and 0.57 ) for these two $W$ values. The fraction of total manure WEP released $[(0.57-0.33) / 0.57=0.42]$ between the $W$ values corresponding to times that runoff began and rain stopped thus represented the fraction of manure WEP that moved to runoff. The P distribution fraction for runoff data from this field plot of Smith et al. (2004) was thus 0.42. We used this 0.42 value in Eq.

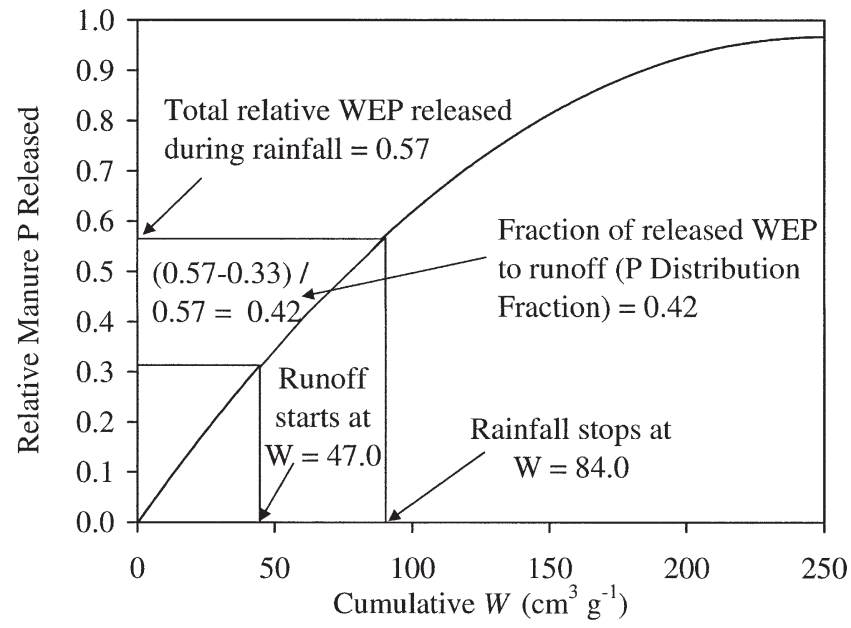

Fig. 4. Illustration of the method used to calculate $P$ distribution fractions, which is the fraction of manure water-extractable phosphorus (WEP) released by rain during a storm that is transported in surface runoff. Data are from Smith et al. (2004). $W$, water to manure ratio.
[3] and [4] instead of the measured runoff to rain ratio of 0.05 .

For all field-plot and soil-box studies, time to runoff, time of total rain duration, and rainfall rate data were known so that $\mathrm{P}$ distribution fractions as shown in Fig. 4 could be calculated. Therefore, we used Eq. [3] and [4], along with new $\mathrm{P}$ distribution fractions to replace runoff to rain ratios, to predict inorganic runoff $\mathrm{P}$ concentrations for data from all three studies. Results in Fig. 3b show that $\mathrm{P}$ distribution fractions gave accurate runoff $\mathrm{P}$ predictions for both soil boxes and field plots, which is an improvement compared with predictions using measured runoff to rain ratios (Fig. 3a).

Vadas et al. (2004) showed that measured runoff to rain ratios were successful in predicting dissolved inorganic $\mathrm{P}$ concentrations in runoff from soil boxes treated with manures. Figure 5 a shows there was a fairly strong empirical relationship between measured runoff to rain ratios and calculated $\mathrm{P}$ distribution fractions for soilbox and field-plot runoff data. For soil boxes where water storage volume is limited, runoff typically begins within a few minutes after rain starts, with nearly all rain converted to runoff thereafter (Vadas et al., 2004). So runoff to rain ratios tend to be close to 1.0 (Fig. 5). Figure 4 shows that for such a scenario, $\mathrm{P}$ distribution
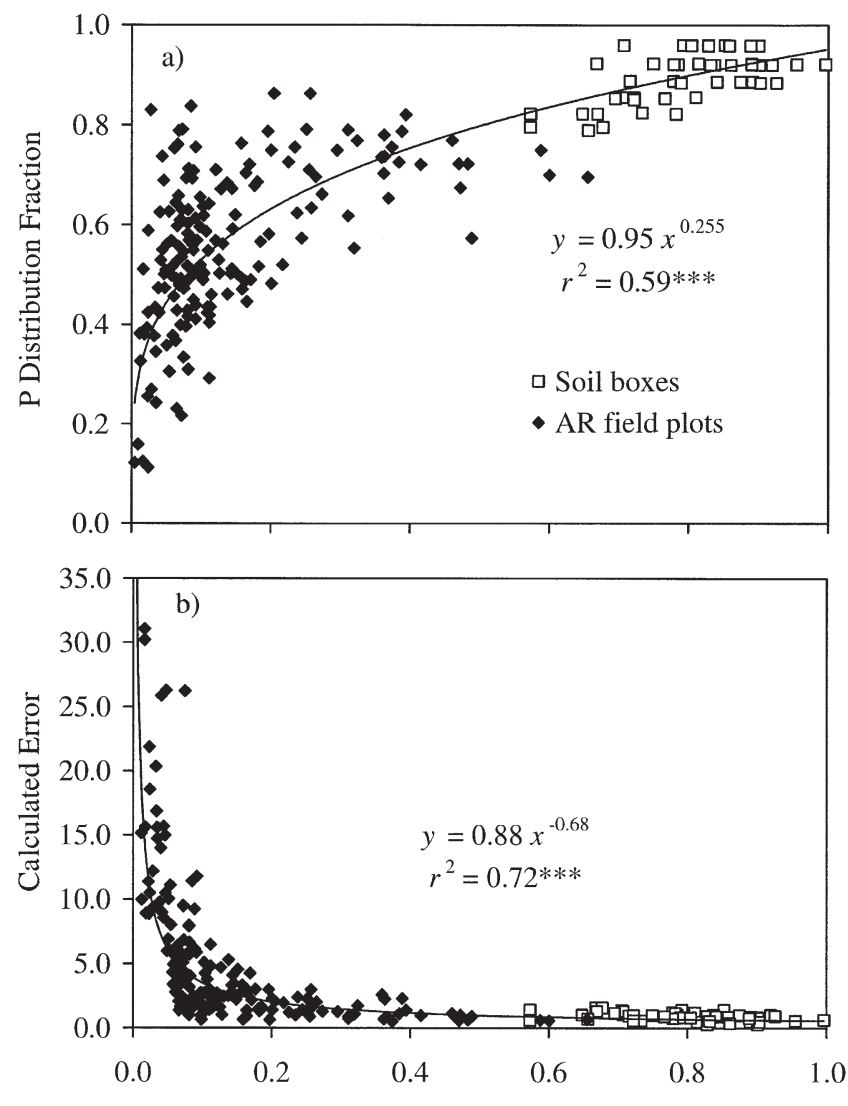

Runoff to Rainfall Ratio

Fig. 5. Data from Haggard et al. (2003), Kleinman et al. (2004), and Smith et al. (2004) showing the empirical relationships between measured runoff to rain ratios and (a) calculated $P$ distribution fractions and (b) error in predicted dissolved $P$ in runoff calculated as (measured/predicted values). The symbol $* * *$ designates significance at the 0.001 probability level. 
fractions will also be close to 1.0 because time to the onset of runoff is relatively short and subsequent $W$ values when runoff begins are low. For soil-box data, $\mathrm{P}$ distribution fractions and runoff to rain ratios were therefore similar enough to give accurate predictions of runoff $\mathrm{P}$ regardless of which one was used.

For field plots, Fig. 5a shows that $\mathrm{P}$ distribution fractions were always greater than runoff to rain ratios. Therefore, runoff to rain ratios caused the underprediction of runoff $\mathrm{P}$ for field plots (Fig. 3a). Water storage volume in soil of field plots can be much greater than soil boxes, and subsequent runoff hydrology is much different (Kleinman et al., 2004). For example, data from Smith et al. (2004) for 32 field plots on the same soil type and across three rainfalls showed that the time to the onset of runoff ranged from 9 to $63 \mathrm{~min}$, and that only 1 to $36 \%$ of rain was converted to runoff. Therefore, two field plots treated with the same manure could produce runoff during the same time span of a single rain event, but with one plot producing much more runoff than another. Figure 4 shows that $\mathrm{P}$ distribution fractions and thus $\mathrm{P}$ concentrations in runoff from the two plots should be similar, while their runoff to rain ratios will differ greatly. In fact, data from Smith et al. (2004) show that for three plots receiving the same poultry litter and the same rain rate, time to runoff varied from only 20 to $24 \mathrm{~min}$, runoff dissolved $\mathrm{P}$ concentrations varied from only 14.9 to $17.9 \mathrm{mg} \mathrm{L}^{-1}$, and $\mathrm{P}$ distribution fractions varied from only 0.46 to 0.52 . However, runoff volumes ranged from 19 to $60 \mathrm{~L}$, and runoff to rain ratios varied from 0.04 to 0.14 . This scenario thus demonstrates why $\mathrm{P}$ distribution fractions give more accurate predictions of $\mathrm{P}$ in runoff from field plots than runoff to rain ratios.

Even though $\mathrm{P}$ distribution fractions are calculated from empirical relationships between manure $\mathrm{P}$ release and water to manure ratio (Fig. 4), their basis provides some insight into the mechanisms controlling $\mathrm{P}$ transfer from surface manures to runoff. First, Eq. [1] and [2] accurately predicted manure $\mathrm{P}$ release to rain water across five leachings (Fig. 2), and Eq. [3] and [4] with $\mathrm{P}$ distribution fractions accurately predicted $\mathrm{P}$ in runoff across multiple rain events (Fig. 3b). Because all these predictions used the same curvilinear relationships (Fig. 1) to calculate relative manure $\mathrm{P}$ release to rain water and to distribute manure $\mathrm{P}$ to infiltration or runoff water, the kinetics of $\mathrm{P}$ release from manures to water is likely consistent for all rain events. What changes across consecutive rain events is the magnitude of the manure WEP pool. As rainfalls leach $\mathrm{P}$ from manures, manure WEP decreases. Thus, less $\mathrm{P}$ is leached with consecutive rainfalls, even though the relative kinetics of $\mathrm{P}$ release for individual rain events remains consistent. Second, the amount of runoff generated relative to the amount of rainfall will not determine $\mathrm{P}$ concentrations in runoff from manures. Rather, it is when the runoff occurs in relation to the kinetics of manure $\mathrm{P}$ release to rain water that controls runoff $\mathrm{P}$ concentrations. The success of our model in predicting $\mathrm{P}$ in runoff from a variety of manure types with either soil boxes or field plots demonstrates its ability to account for a range of hydrology conditions, from when soils are essentially saturated and nearly all rainfall is converted to runoff to when much less rainfall is converted to runoff. For example, when investigating $\mathrm{P}$ in runoff from poultry manure from several independent experiments conducted on the same field plots, Haggard (unpublished data) observed that the relationship between rate of poultry manure WEP application to soils and runoff dissolved $\mathrm{P}$ concentrations is consistently linear, but that the slope of that relationship can vary greatly across different runoff experiments. Therefore, dissolved $\mathrm{P}$ in runoff cannot be accurately predicted based solely on manure WEP application rate. Conversely, Fig. 3b shows that for data from soil boxes to field plots using poultry, swine, or dairy manure across multiple rain events, our more dynamic runoff $\mathrm{P}$ model (Eq. [3] and [4] with $\mathrm{P}$ distribution fractions) accurately predicts $\mathrm{P}$ in runoff from surface-applied manures. This is likely because our model accounts for variability in manure WEP release based on the water to manure ratio for a given storm, and for the dynamics of runoff hydrology.

\section{Implications of Phosphorus Distribution Fractions for Computer Modeling}

Equations [3] and [4] require knowing the volume of rain and runoff to predict $\mathrm{P}$ concentrations in runoff. Since widely used computer models have runoff and rain as variables, these $P$ runoff equations could be easily added to existing models. Conversely, using P distribution fractions instead of runoff to rain ratios requires knowing the rainfall rate and when runoff starts and rain stops during a storm to accurately predict dissolved inorganic $\mathrm{P}$ concentrations in runoff. These time variables are not simulated in models that function on daily or longer time steps, or use a curve number approach to estimate runoff. Therefore, incorporating manure $\mathrm{P}$ runoff equations that use $\mathrm{P}$ distribution fractions into models is potentially more complicated.

Figure 5a shows there was a fairly strong empirical relationship between runoff to rain ratios and $\mathrm{P}$ distribution fractions for soil-box and field-plot runoff data. Such a relationship could be easily added to computer models that have only runoff and rain quantity data available to estimate $\mathrm{P}$ distribution fractions. However, Fig. 5b shows that there was a stronger relationship, based on a test of regression coefficients as described by Snedecor and Cochran (1971), between runoff to rain ratio and the degree of error between measured and original predicted runoff $\mathrm{P}$ concentrations, where runoff $\mathrm{P}$ was predicted using Eq. [3] and [4] and the error was calculated as measured runoff $\mathrm{P}$ divided by predicted runoff P. Since Eq. [3] and [4] are empirical, the runoff to rain ratio could be adjusted according to this degree of error relationship in Fig. 5b, instead of going through the process of determining $\mathrm{P}$ distribution fractions and relating them to runoff to rain ratios as in Fig. 5a.

Therefore, we retested Eq. [3] and [4] for their ability to predict dissolved inorganic $\mathrm{P}$ concentrations in runoff using a new, independent data set from field-plot runoff 
experiments of Kleinman et al. (2001). In this study, runoff plots were established on Lewbeach (coarseloamy, mixed, semiactive, frigid Typic Fragiudept) and Marlow (coarse-loamy, isotic, frigid Oxyaquic Haplorthod) soils in New York and New Hampshire in 2001 or 2002 with either bare soil or cover crops. Fourteen pairs of $1-\times 2-\mathrm{m}^{2}$ runoff plots were installed with the long axis oriented down-slope, which averaged $6 \%$. Runoff plots were isolated on the upper three sides by painted, steel frames driven $5 \mathrm{~cm}$ into the soil and extending $5 \mathrm{~cm}$ above the soil. The lower end of each runoff plot was a covered runoff collection gutter. Dairy slurry manure was broadcast on plots at three rates of 24, 50, or $100 \mathrm{~kg}$ manure total $\mathrm{P} \mathrm{ha}^{-1}$. Approximately $5 \mathrm{~d}$ later, simulated rains were conducted. On the seven pairs of plots in New York, rains were conducted over three consecutive days. On the seven pairs of plots in New Hampshire, only one rain was conducted. Portable rain simulators (Humphry et al., 2002) were placed approximately $3 \mathrm{~m}$ above the soil surface. Rain was delivered at approximately $60 \mathrm{~mm} \mathrm{~h}^{-1}$ until $30 \mathrm{~min}$ of runoff was observed. The time from the onset of rain to the
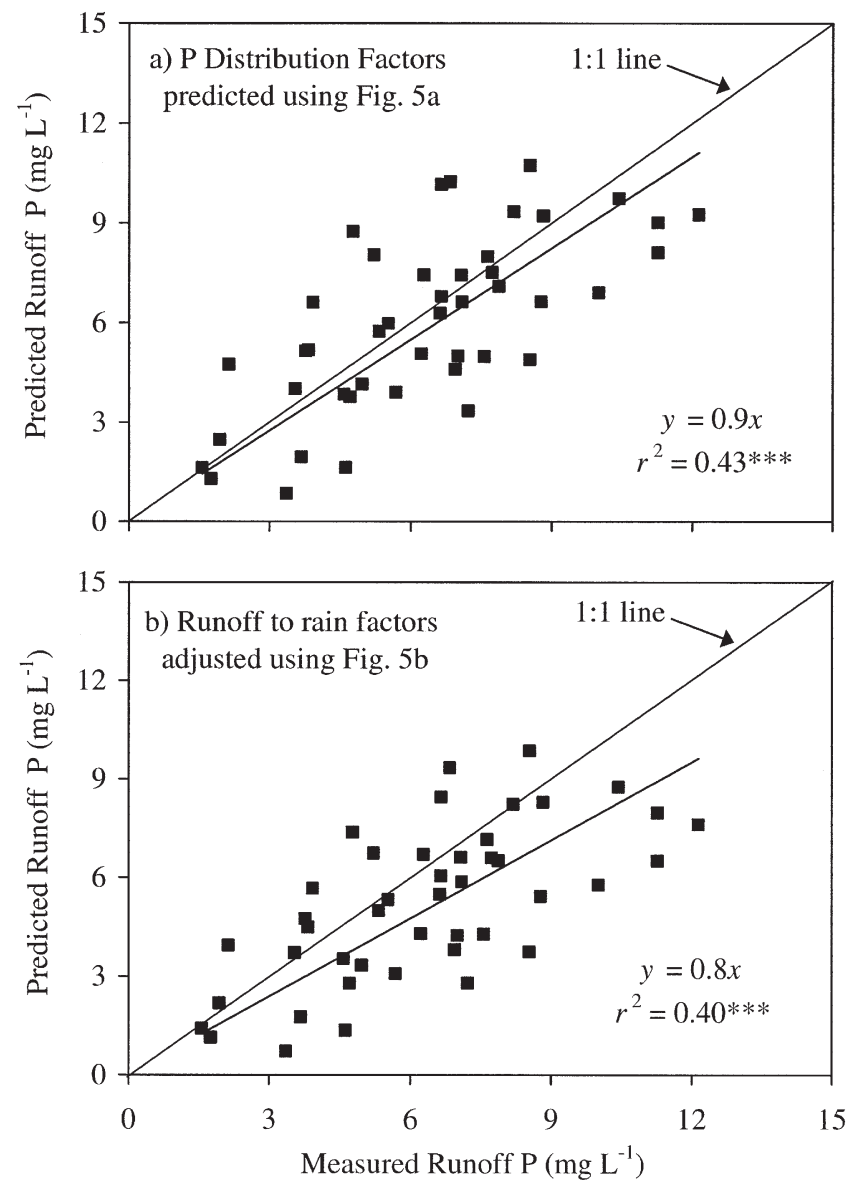

Fig. 6. Relationship between dissolved inorganic $P$ concentrations in runoff from field plots where manures had been surface-applied and subjected to simulated rain as measured by Kleinman et al. (2001) and as predicted by Eq. [3] and [4], using (a) P distribution fractions predicted from runoff to rain ratios with the relationship in Fig. 5a, or (b) measured runoff to rainfall ratios adjusted based on the relationship in Fig. $5 b$. The symbol $* * *$ designates significance at the 0.001 probability level. onset of runoff was recorded, and runoff samples representing the entire $30 \mathrm{~min}$ were filtered through $0.45-\mu \mathrm{m}$ membranes, and analyzed for $\mathrm{P}$ using the method of Murphy and Riley (1962). There was no natural rain in-between simulations.

For our test, we used Eq. [3] and [4], but with measured runoff to rain ratios either replaced with $\mathrm{P}$ distribution fractions, as predicted from runoff to rain ratios and the relationship shown in Fig. 5a, or adjusted for their error according to the relationship in Fig. 5b. Results of the test in Fig. 6 show reliable predictions of $\mathrm{P}$ in runoff whether using predicted $\mathrm{P}$ distribution fractions or adjusted runoff to rain ratios. The results in Fig. 6 are encouraging because they represent a test of our model on different size plots with different soil and manure types and hydrology conditions than those in Arkansas of Haggard et al. (2003) and Smith et al. (2004). Even so, data in Fig. 5 used to determine $\mathrm{P}$ distribution fractions or to adjust runoff to rainfall ratios were still from only soil boxes and small field plots from one location. Runoff hydrology at other or larger field sites or from natural, more variable storms may be subject to relationships different from those we used to predict $\mathrm{P}$ distribution fractions or alter runoff to rain ratios. Therefore, our model should be tested at an even larger field scale.

\section{CONCLUSIONS}

Computer simulation models play a critical role in identifying agricultural areas in a watershed that have a high risk of $\mathrm{P}$ transport in surface runoff. However, widely used models do not simulate $\mathrm{P}$ transport in runoff from surface-applied manures. Therefore, a runoff $\mathrm{P}$ model such as the one developed by Vadas et al. (2004) and modified in our work presented here is needed to accurately quantify $\mathrm{P}$ transport in runoff from surfaceapplied manures. We tested the runoff $\mathrm{P}$ model of Vadas et al. (2004) using rain-runoff data from manured field plots in Arkansas and from soil boxes. The runoff $\mathrm{P}$ model accurately predicted dissolved inorganic P concentrations in runoff from soil boxes, but greatly underpredicted $\mathrm{P}$ in runoff from field plots. The runoff to rain ratio used in the model to distribute manure WEP released by rain into infiltration or runoff water caused the underpredictions. We therefore developed a method to calculate $\mathrm{P}$ distribution fractions to replace runoff to rain ratios. The $\mathrm{P}$ distribution fraction is a function of decreasing incremental WEP release from manure to rain and of the timing of the onset of runoff and the end of rain during a storm. Replacing runoff to rain ratios with $\mathrm{P}$ distribution fractions resulted in accurate predictions of dissolved $\mathrm{P}$ in runoff from surface-applied manures for both soil boxes and field plots.

We observed an empirical relationship between $\mathrm{P}$ distribution fractions and measured runoff to rain ratios for field-plot and soil-box data. We also observed an empirical relationship between measured runoff to rainfall ratios and the error between measured and originally predicted runoff $\mathrm{P}$. Therefore, original underpredictions of runoff $\mathrm{P}$ from field plots could be improved 
by either predicting $\mathrm{P}$ distribution fractions from measured runoff to rain ratios or by adjusting runoff to rain ratios based on this error relationship. We verified our model with both methods for its ability to accurately predict $\mathrm{P}$ in runoff using a new independent set of fieldplot runoff data. We thus demonstrated that our model is successful in predicting dissolved inorganic $\mathrm{P}$ concentrations in runoff from a variety of manure types across a wide range of hydrology conditions. However, subsequent research could include testing the model on an even larger scale, such as fields or small watersheds to determine how well it may account for spatial soil and hydrology conditions occurring within the same rainfall and runoff events, and testing the model across longer time frames, such as months to years to see how well it accounts for changes in manure $\mathrm{P}$ due to chemical or physical weathering.

\section{REFERENCES}

American Public Health Association. 1992. Standard methods for the examination of water and wastewater. 18th ed. APHA, Washington, DC.

Arnold, J.G., R. Srinivasa, R.S. Muttiah, and J.R. Williams. 1998. Large area hydrologic modeling and assessment Part 1: Model development. J. Am. Water Resour. Assoc. 34:73-89.

Bouraoui, F., and T.A. Dillaha. 1996. ANSWERS-2000: Runoff and sediment transport model. J. Environ. Eng. 122:493-502.

Carpenter, S.R., N.F. Caraco, D.L. Correll, R.W. Howarth, A.N. Sharpley, and V.H. Smith. 1998. Nonpoint pollution of surface waters with phosphorus and nitrogen. Ecol. Appl. 8:559-568.

DeLaune, P.B., P.A. Moore, Jr., D.K. Carman, A.N. Sharpley, B.E. Haggard, and T.C. Daniel. 2004. Evaluation of the phosphorus source component in the phosphorus index for pastures. J. Environ. Qual. 33:2192-2200.

Eghball, B., and J.E. Gilley. 1999. Phosphorus and nitrogen in runoff following beef cattle manure or compost application. J. Environ. Qual. 28:1201-1210.

Gibson, G.R., R. Carlson, J. Simpson, E. Smeltzer, J. Gerritson, S. Chapra, S. Heiskary, J. Jones, and R. Kennedy. 2000. Nutrient criteria technical guidance manual: Lakes and reservoirs. EPA822-B00-001. U.S. Gov. Print. Office, Washington, DC.

Haggard, B.E., P.A. Moore, Jr., P.B. Delaune, and D.R. Smith. 2003. Nutrient and B17-estradiol loss in runoff water from various poultry litters. Tps-03-01. In J.D. Williams and D.W. Kolpin (ed.) Agricultural hydrology and water quality [CD-ROM]. 2003 Spring Speciality Conf. Proc., Kansas City, MO. 13-14 May 2003. Am. Water Resour. Assoc., Middleburg, VA.

Heckrath, G., P.C. Brookes, P.R. Poulton, and K.W.T. Goulding. 1995. Phosphorus leaching from soils containing different phosphorus concentrations in the Broadbalk Experiment. J. Environ. Qual. 24:904-910.

Humphry, J.B., T.C. Daniel, D.R. Edwards, and A.N. Sharpley. 2002. A portable rainfall simulator for plot-scale runoff studies. Appl. Eng. Agric. 18:199-204.
Kleinman, P.J.A., P. Salon, and A.N. Sharpley. 2001. Evaluating alternative cover crops for the control of runoff phosphorus losses. In 2001 Annual meetings abstracts. ASA, CSSA, and SSSA, Madison, WI.

Kleinman, P.J.A., and A.N. Sharpley. 2003. Effect of broadcast manure on runoff phosphorus concentrations over successive rainfall events. J. Environ. Qual. 32:1072-1081.

Kleinman, P.J.A., A.N. Sharpley, T.L. Veith, R.O. Maguire, and P.A. Vadas. 2004. Evaluation of phosphorus transport in surface runoff from packed soil boxes. J. Environ. Qual. 33:1413-1423.

Kleinman, P.J.A., A.N. Sharpley, A.M. Wolf, D.B. Beegle, and P.A. Moore, Jr. 2002. Measuring water-extractable phosphorus in manure as an indicator of phosphorus in runoff. Soil Sci. Soc. Am. J. 66:2009-2015.

Leonard, R.A., W.G. Knisel, and D.A. Still. 1987. GLEAMS: Groundwater Loading Effects of Agricultural Management Systems. Trans. ASAE 30:1403-1418.

Miller, W.P. 1987. A solenoid-operated, variable intensity rainfall simulator. Soil Sci. Soc. Am. J. 51:832-834.

Moore, P.A., Jr., T.C. Daniel, and D.R. Edwards. 2000. Reducing phosphorus runoff and inhibiting ammonia loss from poultry manure with aluminum sulfate. J. Environ. Qual. 29:37-49.

Murphy, L.J., and J.P. Riley. 1962. A modified single solution method for determination of phosphate in natural waters. Anal. Chim. Acta 27:31-33.

Novak, J.M., D.W. Watts, P.G. Hunt, and K.C. Stone. 2000. Phosphorus movement through a coastal plain soil after a decade of intensive swine manure application. J. Environ. Qual. 29:1310-1315.

Pierson, S.T., M.L. Cabrera, G.K. Evanylo, P.D. Schroeder, D.E. Radcliffe, H.A. Kuykendall, V.W. Benson, J.R. Williams, C.S. Hoveland, and M.A. McCann. 2001. Phosphorus losses from grasslands fertilized with broiler litter: EPIC simulations. J. Environ. Qual. 30:1790-1795.

Porter, P.S., and C.A. Sanchez. 1992. The effect of soil properties on phosphorus sorption by everglades histosols. Soil Sci. 154:387-398.

SAS Institute. 1999. SAS Version 8. SAS Inst., Cary, NC.

Sharpley, A.N., P.J.A. Kleinman, R.W. McDowell, M. Gitau, and R.B. Bryant. 2002. Modeling phosphorus transport in agricultural watersheds: Processes and possibilities. J. Soil Water Conserv. 57: 425-439.

Sharpley, A.N., and B. Moyer. 2000. Phosphorus forms in manure and compost and their release during simulated rainfall. J. Environ. Qual. 29:1462-1469.

Sharpley, A.N., and S. Rekolainen. 1997. Phosphorus in agriculture and its environmental implications. p. 1-54. In H. Tunney et al. (ed.) Phosphorus loss from soil to water. CABI Publ., Cambridge.

Smith, D.R., P.A. Moore, Jr., D.M. Miles, B.E. Haggard, and T.C. Daniel. 2004. Decreasing phosphorus runoff losses from land-applied poultry litter with dietary modifications and alum addition. J. Environ. Qual. 33:2210-2216.

Snedecor, G.W., and W.G. Cochran. 1971. Statistical methods. 6th ed. Iowa State Univ. Press, Ames.

Vadas, P.A., P.J.A. Kleinman, and A.N. Sharpley. 2004. A simple method to predict dissolved phosphorus in runoff from surfaceapplied manures. J. Environ. Qual. 33:749-756.

Williams, J.R., K.G. Renard, and P.T. Dyke. 1983. EPIC ErosionProductivity Impact Calculator: A new method for assessing erosion's effect on soil productivity. J. Soil Water Conserv. 38:381-383. 